\title{
ガス遮断器開閉極位相制御装置の開発
}

\author{
正員蔦田広幸 正員 平位隆史 正員 香山治彦 \\ 正員 伊藤 弘基 正員 宇佐美 照夫 (三菱電機)
}

\section{Development of Synchronous Switching Controller for Gas Circuit Breakers.}

Hiroyuki Tsutada, Takashi Hirai, Haruhiko Kohyama,

Hiroki Itoh, Teruo Usami (Mitsubishi Electric Corporation)

\begin{abstract}
Synchronous switching controller (SSC) for gas circuit breakers (GCB) has been developed. SSC is able to close and open a GCB at the appropriate point on wave for minimizing the switching surges. This paper proposes the new synchronous switching algorithm to minimize the control delay time, and the control error for the desired point on wave. New algorithm for (1) detecting voltage and current zero crossing points and (2) predicting the next operation time of GCB is introduced. $145 \mathrm{kV} \mathrm{GCB}$ with SSC built in new algorithm has been tested several condition. SSC performed well from - 30 degrees $\mathrm{C}$ to 60 degrees $\mathrm{C}$ at various control voltage condition and the standard deviation from the taget phase is within $0.5 \mathrm{msec}$. And the closing at two target points with voltage zero and peak works well in a capacitive load circuit at $145 \mathrm{kV}$.
\end{abstract}

キーワード：開閉極位相制御，ガス遮断器，コンデンサバンク開閉，シャントリアクトル開閉

Keywords : controlled switching, gas circuit breaker, capacitor bank switching, shunt reactor switching

\section{1.まえがき}

ガス遮断器開開動作時に発生する過電圧および過電流 は機器の寿命・䋓縁酎力・系統電圧の安定性に影響を及 ばすことが知られている(1)。例えば，無負荷変圧器の励 磁投入時に遮断器の投入位相によっては過大な励磁突入 電流が発生し，これに伴う系統電圧の変動, 保護リレー の䛊動作等を誘発する可能性がある。また，調相用りア クトル遮断時には, 遮断器極間の再発弧により遮断器電 極の消耗量の増加や，過大な再発弧過電圧が発生する可 能性がある(2)。こ机らの遮断器開閉時の過電圧・過電流 は, 遮断器を系統電压または電流の特定位相において開 閉することにより抑制することができる(3)。こような 方式を遮断器開閉極位相制御方式と呼んでおり，90年代 後半から欧米を中心に急速に普及してきている(か)。

通常, 制御室からの開閉極指令が遮断器の操作コイル を直接駆動することで開閉動作を開始し，一定時間経過 後に主回路接点を開閉する（以下，この時間を開閉極時 間と呼ぶ)。これに対して開閉極位相制御では, 系統電圧 または電流の目標位相において主回路接点を開閉させる ため，開閉極指令が入力されると，目標位相から予測さ れる開閉極時間だけさかの伊った時点で, 操作コイルを 駆動! 怘せ開閉動作を行う。つまり指令入力から操作コ イルを駆動させて開閉動作を開始させるまでの時間（以
下，同期遅れ時間と呼ふ）を変化させることで開閉位相 の制御を行っている。

制御という観点から見ると，制御による遅れ時間であ る同期遅れ時間を小さくすることは重要な課題である。 そこで本報告では，開閉極位相制御を行う上で，同期痋 れ時間を小さくする方式を提案する。

また，制御精度を向上させることも重要な課題である。 開閉極位相制御の制御精度は，目標位相を決定する際の 基準となる系統電圧または電流位相の検出精度，周囲温 度・制御電圧等の遮断器環境条件により変化する開閉極 時間の予測精度, 及び遮断器の機械的動作ばらつきに依 存している。本報告では, 目標位相検出の基準となる系 統電圧または電流の零点を精度良く㮩出する方式, 及び 遮断器の開閍極時間を精度良く予測する方式を提案する。

また，提案したアルゴリズムを実装した開閉極位相制 御装置（Synchronous Switching Controller:SSC) を 開発し，開閉試験及び投入・遮断試験を行ったので，そ の結果について報告し, 提案するアルゴリズムの有効性 及びSSCの性能について示す。

\section{2.開閉極位相制御方式について}

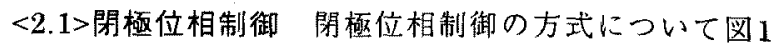
のフォー及び図2のタイムチャートを用いて説明する。 閉極の場合は機械的な閉極以前にプレアークの発生によ 
り電気的な通電，すなわち投入が行われるので，プレア 一クの発生点（投入点）を目標位相に制御することが要 求される。零点から時間 $\mathrm{T}_{\text {phase }}$ た経過した目標位相 $\mathrm{t}_{\text {make }}$ で投入するには，目標位相からプレアータ時間 $\mathrm{T}_{\text {are }}$ を考 慮した予測投入時間 $\mathrm{T}_{\text {making }}$ 以前に，遮断器操作装置を駆 動させる信号である閉極制御信号を出力すればよい。

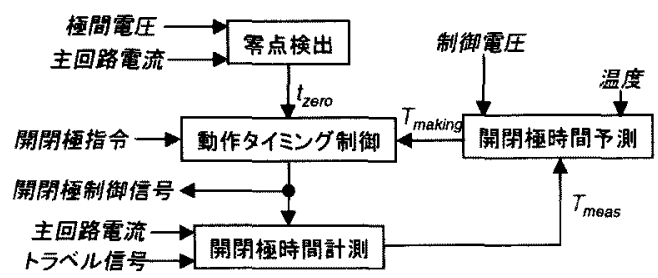

図1 位相制御フロー

Fig. 1. Flow chart of synchronous switching.

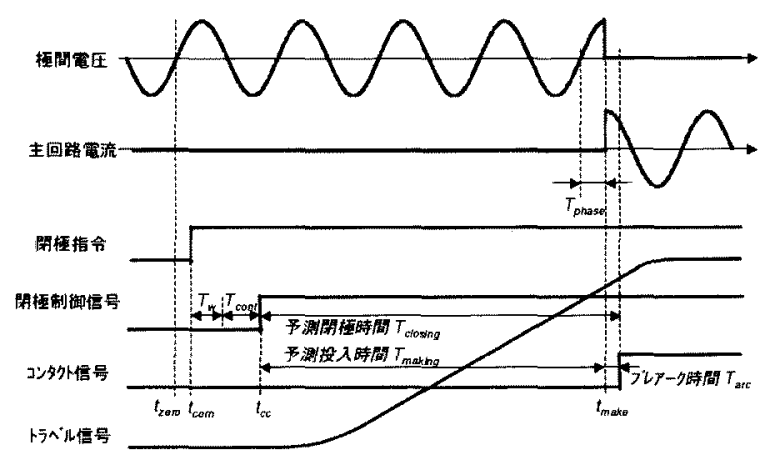

図2 閉極位相制御タイムチャート

Fig.2. Time chart of controlled switching (close)

制御装置に時刻 $t_{\mathrm{com}}$ で閉極指令が入力されると，遮断 器閉極時間である予測閉極時間 $\mathrm{T}_{\text {closing }}$ を動作環境条件に 基づいて予测し，あらかじ求めておいたプレアータ時 間 $\mathrm{T}_{\mathrm{arc}}$ を差し引いて予测投入時間 $\mathrm{T}_{\mathrm{making}}$ を求める(動作時 間の予測方法については4章を参照)。

次に, 目標位相から $\mathrm{T}_{\text {making }}$ 手前の時点 $\mathrm{t}_{\mathrm{cc}}$ で閉極制御信 号が出力されるように，閉極制御信号の出力を崖らせる 時間幅であるデイレイ時間 $\mathrm{T}_{\text {cont }}$ を計算し，これを制御装 置のタイマにセットする。以上の計算はマイクロプロセ ッサで計算時間 $\mathrm{T}_{\mathrm{w}}$ 以内に行うようにする。計算時間 $\mathrm{T}_{\mathrm{w}}$ が経過するとタイマをスタートさせて、デイレイ時間 $\mathrm{T}_{\text {cont }}$ が経過した時点 $\mathrm{t}_{\mathrm{cc}}$ で閉極制御信号を出力させて

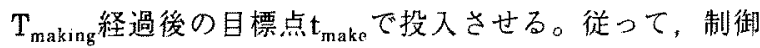
装置の同期迤れ時間は $\mathrm{T}_{\mathrm{w}}+\mathrm{T}_{\text {cont }}$ となる。

$<2.2>$ ディレイ時間の算出 ディレイ時間 $\mathrm{T}_{\text {cont }}$ を算出す るため，閉極時は極間電圧の零点，開極時は主回路電流 の零点を基準として用いる。本方式では開閉極指令入力 の有門に関わらず常に零点を検出しておき，指令が入力 れた時点で最近の零点時刻 $\mathrm{t}_{\mathrm{zero}}$ を用いて直ちに $\mathrm{T}_{\text {cont }}$ を 算する（零点の検出方法については3章を参照）。
零点時刻 $\mathbf{t}_{\mathrm{zer}}$. 指令入力時刻 $\mathbf{t}_{\mathrm{com}}$. 閉極制御信号出力時 剂 $t_{\mathrm{cc}}$ 及び計算時問 $\mathrm{T}_{\mathrm{w}}$ を用いると式(1)の関係となる。

$$
T_{\text {cont }}=t_{c c}-t_{c o n}-T_{w^{\prime}}=\left(t_{c c}-t_{\text {zero }}\right)+t_{\text {zero }}-t_{c o m}-T_{w}
$$

一方，目標位相で投入するために，閉極制御信号出力 時刻 $\mathrm{t}_{\mathrm{ec}}$ と零点時刻 $\mathrm{t}_{\mathrm{zero}}$ との差が满たすべき条件は式(2)で 示され，(1)(2)を用いてデイレイ時間 $\mathrm{T}_{\text {cont }}$ が式(3)で得ら れる。

$$
\begin{aligned}
& \left(t_{c r}-t_{z e r o}\right)=\frac{1}{2 f} n-\left(\left(T_{\text {making }}-T_{\text {phase }}\right) \bmod \frac{1}{2 f}\right) \\
& T_{\text {cont }}=\frac{1}{2 f} n-\left(\left(T_{\text {naking }}-T_{\text {phtese }}\right) \bmod \frac{1}{2 f}\right)+t_{z e r o}-t_{\text {comr }}-T_{w}
\end{aligned}
$$

たたし，fは系統の周波数 $(\mathrm{Hz}), \mathrm{T}_{\mathrm{phase}}$ は零点と目標位 相との時間差, $(\mathrm{A} \bmod \mathrm{B})$ は $\mathrm{A} \mathrm{B} て ゙$ 割った剩余, $\mathrm{n}$ は $\mathrm{T}_{\mathrm{con}}$ $\geqq 0 か つ \mathrm{~T}_{\text {cont }}$ が最小となる整数值とする。

従来より提案されている万法では，開閉極指令が入力 されてから次の零点を検出し，これを基準としてディレ イ時間を変化させて位相制御を行っていたので，開閉極 指令のタイミンダによっては零点検出までの間にむだ時 間が存在し，結果として同期遅れ時間が大きくなるとい う問題があった(6)(7)。本方式では，計算時間 $\mathrm{T}_{\mathrm{w}} \doteqdot 0$ の時， どのようなタイミングの開閉極指令入力に対しても，半 サイタル以下の同期遅れ時間で遮断器に開閉極制御信号 を出力することが可能である。

$<2.3>$ 開極位相制御 次に開極位相制御方式に・ついて図 3の夕イムチャートを用いて説明する。開極の場合は， アーク時間を制御することが求められる。アーク時間と は，接点が機械的に開離してから実際に電流遮断される 電流零点までの時間であり，これを制御するには機械的 な開極点を目標位相に制御する必要がある。零点から時 間 $\mathrm{T}_{\mathrm{phase}}$ だけ経過した目標位相 $\mathrm{t}_{\mathrm{make}}$ で開極するためには， 目標位相より予測開極時間 $\mathrm{T}_{\text {opening }}$ 以前に, 遮断器操作装 置を駆動させる信号である開極制御信号を出力すればよ い。計算方法は閉極の場合と同様である。

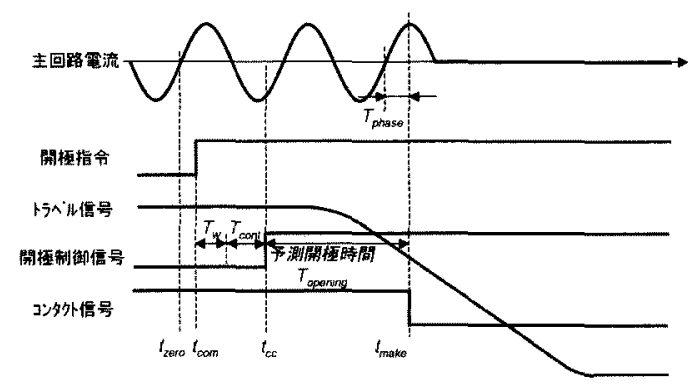

図3開極位相制御タイムチャート

Fig.3. Time chart of controlled switching (open).

\section{3.零点検出方式}

前述したように，開閉極位相制御における目標位相の 
基隼として電圧または電流信号の零点を用いている。そ のため位相制御の精度を向上させる上で，零点を精度よ く検出することは重要である。本章では，通常開閉時に おける零点検出方式について検討した結果を述べる。 $<3.1>$ 検出フロー 零点㛟出の精度を低下させる要因と して以下のような項目が想定される。

(1) 測定系に重畳するホワイトノイズ

(2) 測定系・原信号に重畳するインパルスノイズ

(3) 測定系に重畳する高調波

これらを除去する目的で, 図4に示す検出フローで測 定信号から零点検出を行った。

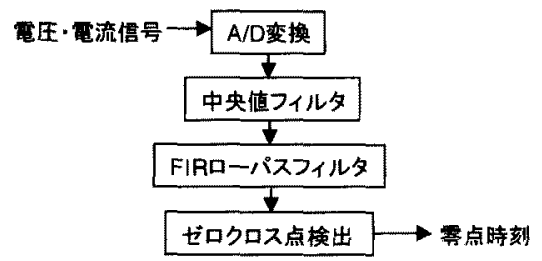

図4零点検出フロー

Fig.4. Flow of detecting zero crossing points.

(2)については，発生するインパルスノイズの周波数帯 域はMHz帯域のものが大半であり減衰時間も短いので, ヒゲ状のノイズとなる。これを取り除くことを目的とし て中央值フィルタを前処理として施した。

(3)については, 対象遮断器の周辺機器により測定系に 3次及び5次高調波が最大 $5 \%$ 程度重睤することが考えら れるが，この場合においても位相制御精度を定格として 保証する必要がある。位相情報が重要であるため，直線 位相特性を持ちながら高調波成分を除去することが可能 なFIRローパスフィル夕を使用した。これにより(1)の影 響も低隇される。

以上のようにフィルタリングされた波形が, ゼロクロ スする前後のサンプリング点を逐次検出し，サンプリン グ点間を直線内挿することで零点時刻を検出する。

$<3.2>$ 検出シミュレーション 前記零点検出方式の妥当 性を検証するために，60Hz基本波に3次高調波 $5 \%$ と 5 次 高調波 $5 \%$ をランダム位相で重量させて波形を作成し，零 点検出のシミュレーションを行った。

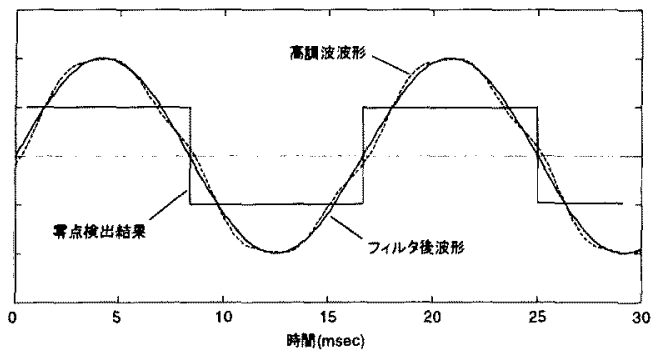

図5 高調波重鲳時の零点検出結果

Fig.5. Result of detecting zero crossing points.
上記条件下では，元信号の零点は基本波零点に対して 最大士0.26m $\mathrm{mec}( \pm 6.69$ 度 $)$ 変動するが，本手法適用後 の零点檢出誤差は $\pm 0.07 \mathrm{msec}( \pm 1.46$ 度 $)$ 以下となるこ とを確認した。本手法により，高調波重疊時においても $\pm 0.1 \mathrm{msec}$ 以下の精度で零点検出可能であることが確認 された。図5に検出結果の一例を示す。フィルタにより 高䛺波成分が除去された波形から精度よく零点が検出さ れていることがわかる。

\section{4.開閉極時閔予測}

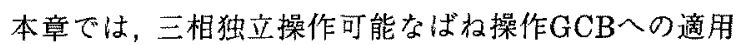
を目的として，遮断器本体の動作特性について検討を行 い，それに基づいて動作時間補正方式の検討を行った結 果について述べる。

$<4.1>$ 遮断器特性の検討 遮断器の操作電圧である制御 電圧, 及び周囲温度を変化させた時の開閉極時間の変動 について検討した。供試器として三相独立操作が可能な $145 \mathrm{kV} 40 \mathrm{kA}$ ばね遮断器を使用し, 制御電在及び周囲温度 を変化させて開閉極時間を各20回測定した。平均特性を 図6及び図7に示す。
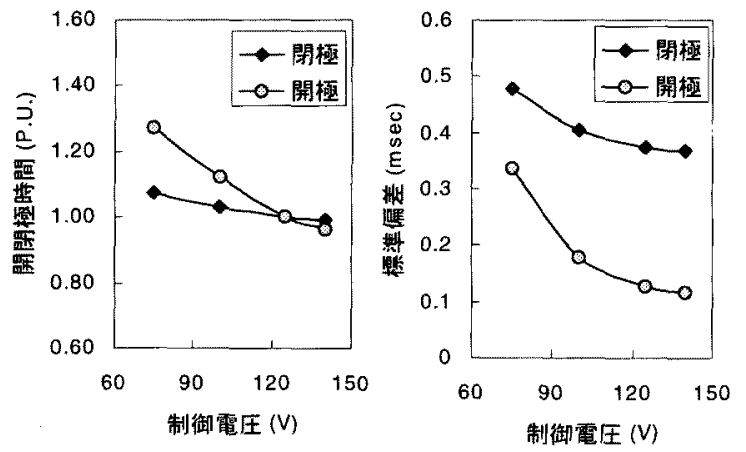

図 6 制御電圧一開閉極時間特性

Fig.6. Operating characteristics vs. control voltage.
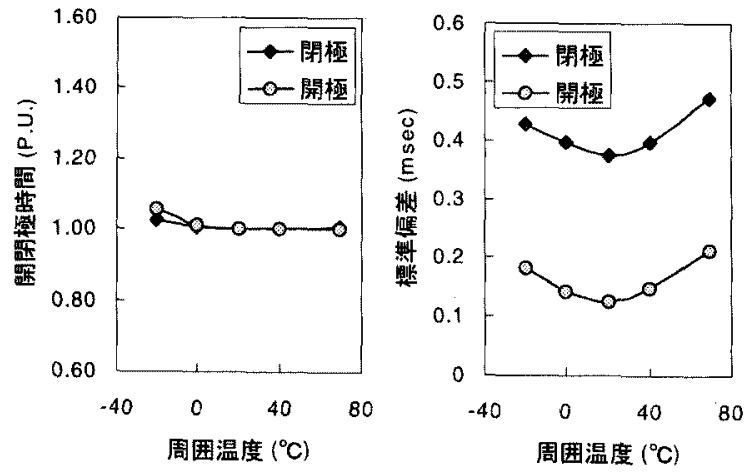

図7 周囲温度一開閉極時間特性

Fig.7. Operating characteristics vs. temperature. 
図6及び図7から，制御電圧及び周囲温度により遮断器 の平均開閉極時間が变化していることがわかる。これは， 遮断器操作装置の係止機構部における操作コイルの操作 力や遮断器可動部の摩擦力が制御電圧及び温度に依存し ているためであると考えられる。なお，組み立て条件等 により各々の遮断器における平均動作速度には多少の差 があるものの, 同一型式の遮断器においては, 制御電圧. 周囲温度による開閉極時間の変化特性は各台および各相 毎にほほ同一であることを確認している。そこで，制御 電圧及び周囲温度を変数とした補正時間の関係を予め求 めておき，動作時の制御電生・周囲温度を計測して補正 することで開閉極時間の予測が可能であると考えられる。

次に, 遮断器の多数回動作による経時变化について検 討した。前記と同型遮断器を用い, 制御電圧及び周囲温 度を一定として多数回動作させた時の平均開閉極時間の 変化について図8に一例を示す。

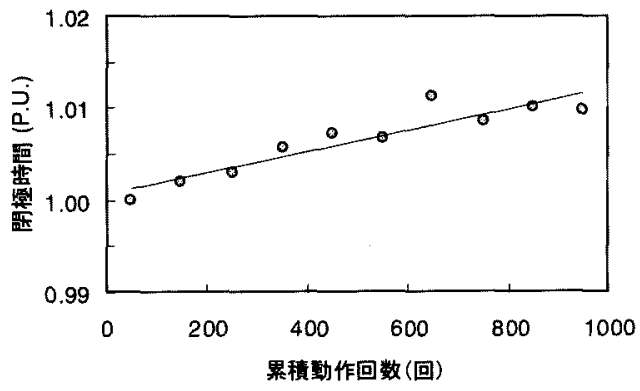

図8閉極時間の経時変化の一例

Fig.8. Example of long term closing chracteristics.

図8に示されるように，経時変化により閉極時間の中 心値が変化していることがわかる。このような経時変化 に加え，電流開閉に伴う接点摩耗の影響や各台毎の微妙 な特性差を吸収するという点で, 各回の実開閉極時間を 次回以降の開閉極時間予測にフィードバックすることが 必要であると考えられる。

$<4.2>$ 動作時間補正方式の概要 前節の検討より, 遮断 器の開閉極時間は制御電圧・周囲温度・絜積動作による 接点摩耗・経時変化・個別の特性差等の要因により中心 值が変化することがわかった。そのため，

（1）制御電圧・周囲温度に基づいた補正時間 $\Delta \mathrm{T}_{e n \mathrm{n}}$

（2）過去の動作履歴に基づいた補正時間 $\Delta \mathrm{T}_{\text {const }}$

を開極・閉極についてそれぞれ求め，標準環境条件（= 例之ば制御電圧 $125 \mathrm{~V}$ ・周囲温度 $20^{\circ} \mathrm{C}$ ) の平均開閉極時間 として与えられた標準開閉極時間 $\mathrm{T}_{\mathrm{x} / \mathrm{d}}$ を補正して，予測 開閉極時間を式(4)により求める。

$$
\text { 予測開閉極時間 }=\mathrm{T}_{\text {std }}+\Delta \mathrm{T}_{\mathrm{env}}+\Delta \mathrm{T}_{\text {const }}
$$

以下に，制御電圧及び温度補正，及び動作履歴補正の 詳細について述べる。
$<4.3>$ 制御電圧・温度補正 制御電圧及び周囲温度によ る補正時間 $\Delta \mathrm{T}_{\text {env }}$ については，予め各動作条件に抢ける 平均開閉極時間を計測し，標準開閉極時間 $\mathbf{T}_{\text {std }}$ に対する 差の関係を図9に示すようなメッシュマップの形式で作 成しておく。前節の検討より，このメッシュマップデー 夕は同型遮断器に対して共通の変化特性として使用する ことができる。

開閉極指令が与えられた時点で，その時の制御電圧及 び周囲温度における補正時間 $\Delta \mathrm{T}_{\mathrm{env}}$ をメッシュマップを 用いて算出する。現在の動作条件における補正時間が存 在しない場合は, 現在の動作条件に最も近い4点の補正 時間データから双一次補間を用いて内挿する。

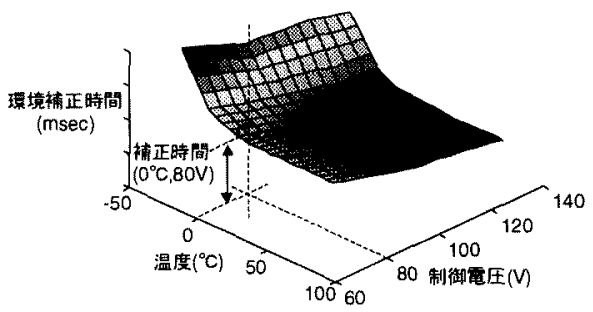

図9制御電圧・温度補正マップ

Fig.9. Calibration time map.

<4.4>動作履歴㭪正 投入時には主回路電流，遮断時に は遮断器可動部の動作行程を表すトラベル信号に基づい. て開閉極時間を各動作毎に計測し, 最近10回の動作履歴 に基ついてて補正時間 $\Delta \mathrm{T}_{\text {const }}$ を算出する。

ここでは主回路電流に基づいた閉極時間の算出方法に ついてのみ詳細に述べる。図10に示すように，投入点で は電流波形に不連続点が存在する。そこで，測定された 主回路電流に不連続点を強調するハイパスフィルタを施 し，フィルタ後波形が閾值を超えた点を投入点として検 出し，投入時間と投入位相を得る。予为対象遮断器の極 間耐電圧減少率を求めておき，得られた投入位相との関 係から遮断器のプレアーク時間を推定する。閉極時間は, 得られた投入時間に上記プレアーク時間を加えた值とし て算出する。

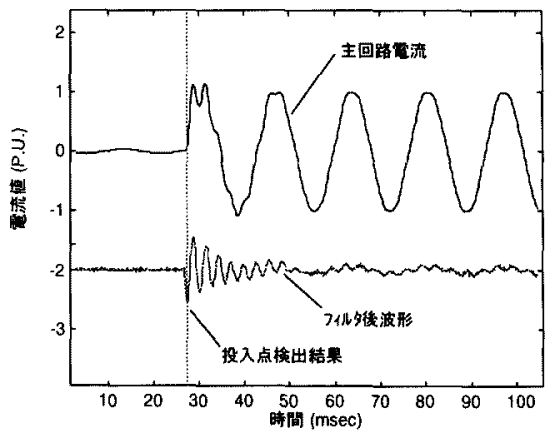

図10 投入点検出結果

Fig.10. Result of detecting making points. 
以上のように計測された開閉極時間を用いて，式(5) により補正時間 $\Delta T_{\text {const }}$ を算出し, 予測開閉極時間の定常 誤差を開極・閉極それぞれについて補正する。

$\Delta T_{\text {const }}=\sum w(n)\left\{\right.$ 計測開閉極時間 $\left.(n)-T_{s t d}(n)-\Delta T_{c n v}(n)\right\} \quad$ (5)

ただし，nは0〜9の整数値，w(n)は重み係数である。

重み係数は総和が1となるように設定する。

最近の動作時デー夕の重み係数を大きくするほど, 開 閉極時間の変動に対する応答性がよくなるが, 開閉極時 間のばらつきの影響を受けて安定性が悪くなる傾向があ るため, 操作装置の特性に応じた係数の設定を行う必要 があると考えられる。

そこで係数間の比率である $\mathrm{w}(\mathrm{n}) / \mathrm{w}(\mathrm{n} \cdot 1)$ を係数增加率 と定義し, 係数増加率を変化させて計測値と予測值の誤 差の標準偏差が最小となるような係数を選択することと した。係数増加率を大きくするほど，最近の動作時のデ 一タの重み係数を大きくしていることに相当する。また 係数増加率 $=1$ の場合とは, $\mathrm{w}(0) \sim \mathrm{w}(9)=0.1$ に相当する。

4.1節の検討で得られた各条件の開極時間データに対 し制御電圧・温度補正を施した上で, 係数増加率を様々 な値に変化させて動作履歴補正の効果を調べた。予測䛊 差の標準偏差を調べた結果を図11に示す。

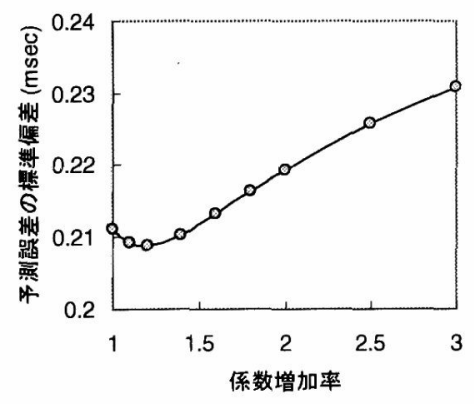

図 11 係数増加率と予測誤差

Fig.11. Predicting error chracteristics vs. coefficients.

図からわかるように係数増加率を徐々に小さくしてい くと, 開極時間のばらつきに対する安定性が良くなり, 予測誤差が小さくなっていく。しかしある程度以上小さ くすると，ばらつきに対する安定性が向上するものの， 開極時間の定常的なずれに対する応答性が悪くなるので， 逆に予測誤差が増大する。よって，このグラフの極小值 を本遮断器の係数として用いれば最適な制御が行われる と考えられる。

5.ハードウェア

前述したアルゴリズムを実装したSSCの外観を図 12 に示し，H/Wブロック図を図13に示す。SSCの主要特徴 は以下の通りである。

（1）指令入力部及び制御信号出力部を 3 相分 (6点) 備え, 各相毎に開閉極タイミングの制御を行うことが可能。
（2）32ビットデジタルリレー用CPUを採用し，高い信頼 性を確保するとともに, 制御演算・動作結果解析等 を高速に実行可能。

（3）遮断器の動作時刻・温度 ·制御電圧 · 油圧 · 開閉極 時間等の動作履歴, 及び動作時の主回路電流・極間 電圧・トラベル信号の波形及びアラーム信号をフィ ールドネットワークを通じて上位系PCからモニタ リングが可能。

（4）遮断器操作ハウジングまたは現地制御盤に設置可能 とするため, 電気的サージや温度変化等に対する耐 環境性を確保。

（5）コントローラ及びセンサの自己診断機能や位相制御 の成否・再点弧の有無等を判定する機能を有し, 異 常検出時にはアラーム出力と共に装置を短絡あるい は開放で固定可能。

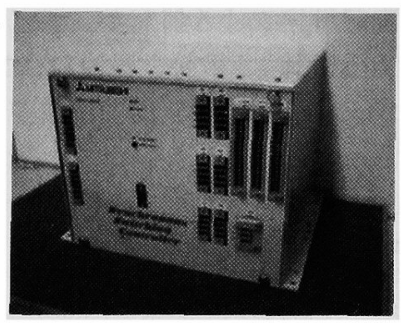

図12 SSC外観

Fig.12. Synchronous switching controller.

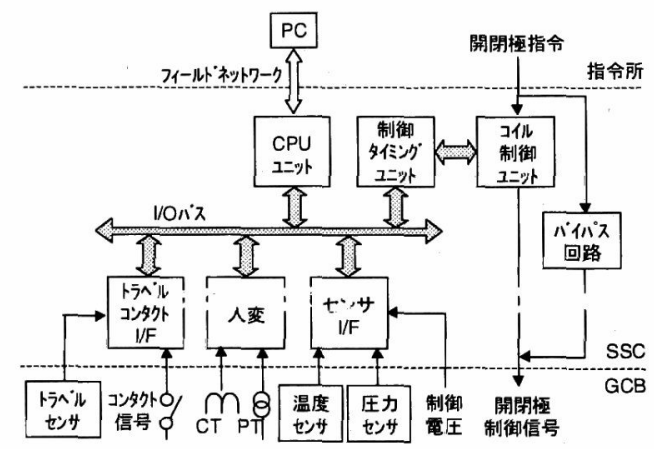

図13 H/Wブロック図

Fig.13. Hardware architecture of SSC.

\section{6.試験}

$<6.1>$ 単体での制御性能評価 SSC単体の機能を確認す るため, 指令入力後, 一定時間で接点のオンオフを行う 遮断器模擬回路を用いて試験を行った。予め模擬回路の 動作ばらつきが $1 \mu$ sec以下であることを確認した。SSC の系統電圧及び電流入力部に $60 \mathrm{~Hz}$ 正弦波の基準信号を 直接入力し, 目標開閉極位相を電気角 0 度として, ラン ダムなタイミングで開閉極指令を入力した時の誤差を調 ベた（図14）。基準となる系統電圧信号または電流信号 にノイズがない条件下では, 制御誤差は土 $10 \mu \mathrm{sec}$ 程庨で あった。 


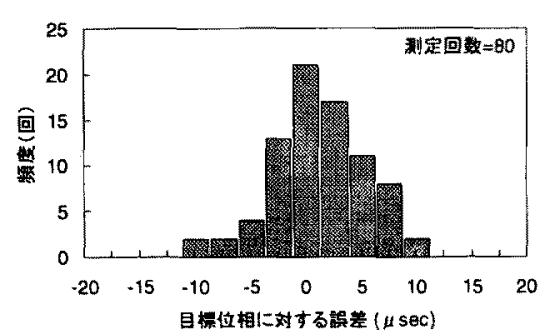

図14 SSC単体での制御誤差

Fig.14. Control error of SSC.

$<6.2>$ 開閉試験 次に遮断器と組み合わせた状態で，環 境条件の変動に対する制御性能を評価するため，三相独 立操作可能な $145 \mathrm{kV} 40 \mathrm{kA}$ ばね操作ガス遮断器を用いて 開閉試験を行った。主回路にはAC125Vを印加し，制御 の基準電圧とした。制御電压一定条件として周囲温度を $-30^{\circ} \mathrm{C} \sim+60^{\circ} \mathrm{C} て ゙$ 変化させた時の制御誤差を図 15 , 図16 に示す。周囲温度一定条件で制御電圧を75V〜140Vで変 化させた時の制御誤差を図17，図18に示す。図中左側の プロットは誤差の平均值, 上下のバーは誤差の標準偏差 を示し，図中右側は全測定における誤差分布を示してい る。目標開閉極位相は電気角0度とした。

周囲温度・制御電压の変動に関わらず，予測誤差は0 を中心に正規分布状となっており，定常誤差もなく良好 :位相制御てきていることがわかる。

各動作条件における誤差の標準偏差值は，图6及び図7 で示した遮断器単体での動作ばらつきとはほ一致してい ること,及び制御装置単体での動作ばらつきは土10 $\mu \mathrm{sec}$ 程度であったことから，同一環境条件において制御誤差 が発生する要因の大半は遮断器本体の機械的な動作ばら つきに起因していると考えられる。本遮断器との組み合 わせでは標準偏差 $\sigma は 0.5 \mathrm{msec}$ 以下であり，CIGRE報告

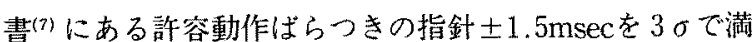
足していることから，開閉極位相制御を奏施するための 十分な性能を有しているといえる。

制御電压一定. 常温条件下 (DC125V, $10^{\circ} \mathrm{C}-30^{\circ} \mathrm{C}$ ) で多数回動作させた時の制御䛊差（開極時）を図19に示 す。図8で述べた経時変化による開極時間の変化に対し ても，定常䛃差なく制御できていることがわかる。

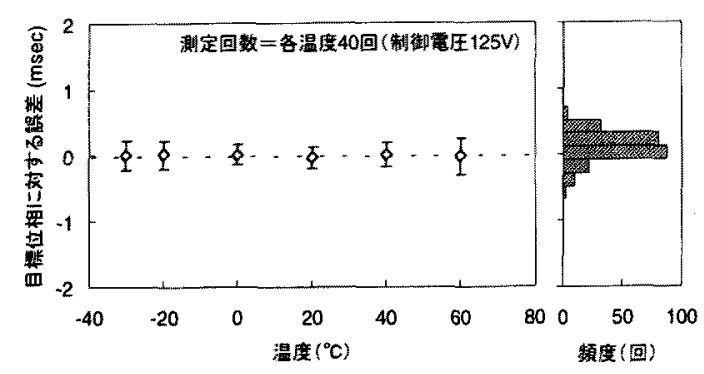

図15周囲温度変化時の開極位相制御誤差

Fig. 15. Control error of the opening vs. temperature.

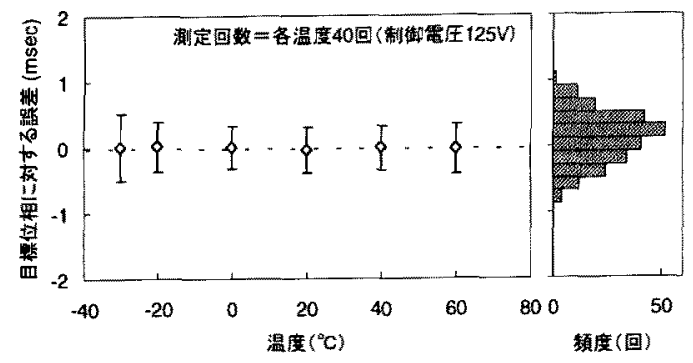

図16 周囲温度変化時の閉極位相制御誤差

Fig.16. Control error of the closing vs. temperature.

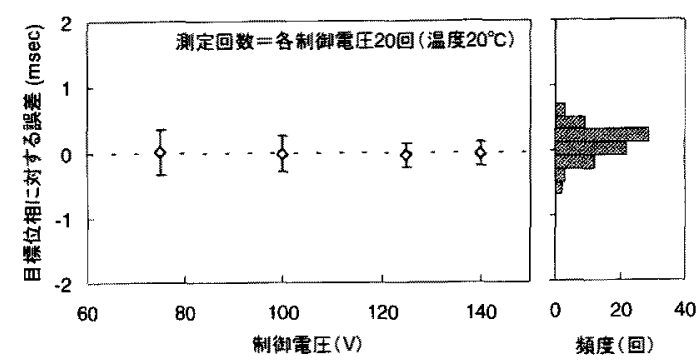

図17 制御電圧变化時の開極位相制御誤差

Fig. 17. Control error of the opening vs. control voltage.

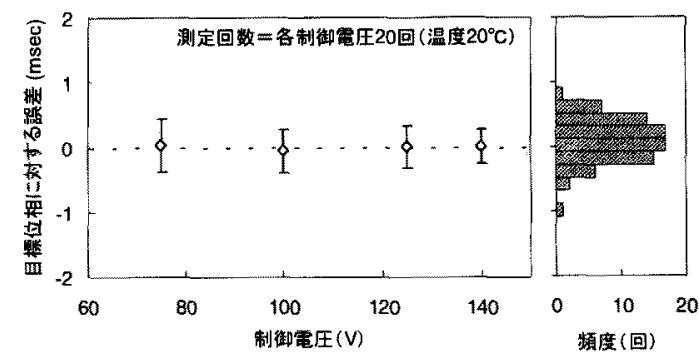

図18 制御電圧変化時の閉極位相制御颚差

Fig. 18. Control error of the closing vs. control voltage.

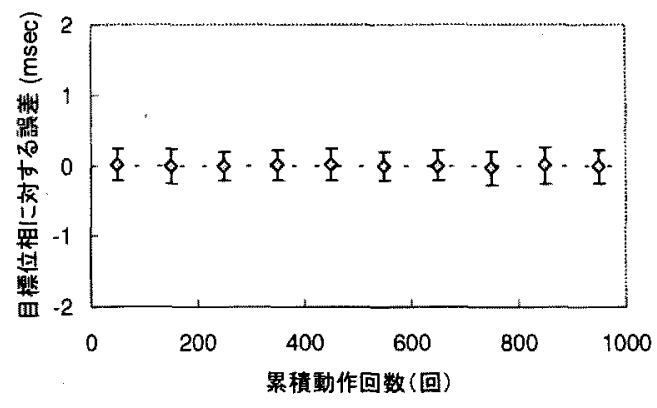

図19 多数回動作時の開極位相制御誤差

Fig.19. Control error of the long terms opening

$<6.3>$ 投入試験 次に寒負荷での制御性能を評価するた め，図20に示す回路で零点投入及びピー夕点投入の試験 を行った。用いた供試器は前節と同様である。遮断器の 動作ばらつきとプレアータ時間を考慮し，需点投入では 
目標投入位相を 13 度, ピーク点投入では目標投入位相を 86度とした。図21に零点投入の結果を示し, 図22にピー ク点投入での結果を示す。目標投入位相に対して最大士 $1 \mathrm{msec}$ 程度の誤差であり，実負荷でも良好に位相制御で きていることが確認できる。また，ピーク投入時のサー ジに対してもSSCが問題なく動作することを確認した。

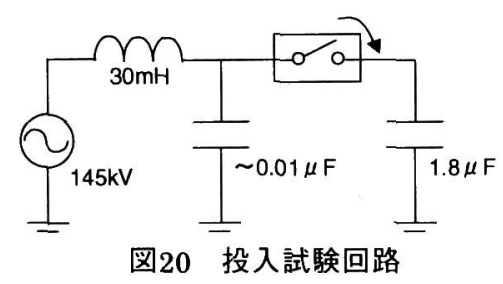

Fig.20. Circuit of making test.

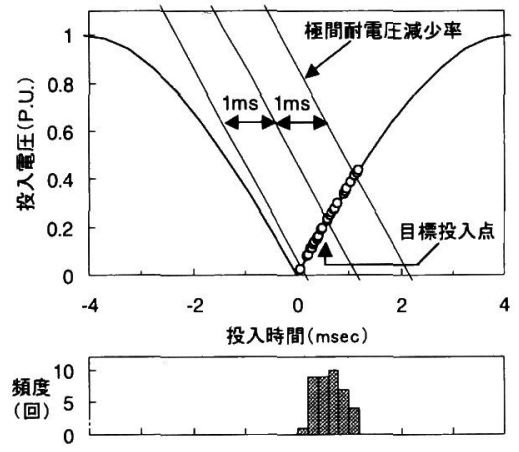

図21 零点投入試験結果

Fig.21. Result of synchronous closing at voltage zero.

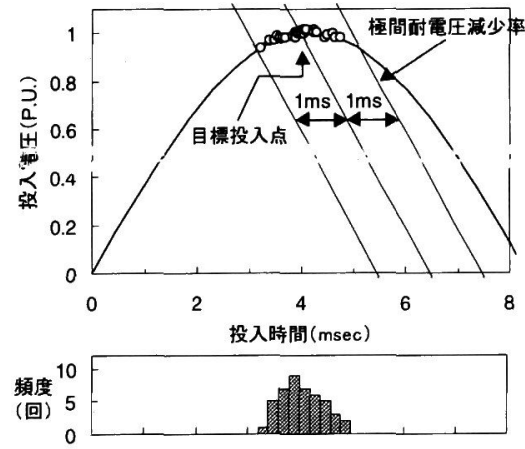

\section{図22 ピーク点投入試験結果}

Fig.22. Result of synchronous closing at voltage peak.

\section{7.むすび}

本報告では，半サイクル以下の同期遲れ時間で位相制 御可能な制御アルゴリズムを提案するとともに，制御精 度を向上させる方法について検討し，提案したアルゴリ ズムを実装し大開閉極位相制御装置について述べた。 $145 \mathrm{kV}$ 遮断器に搭載して評価を行った結果, 開閉極位相

制御GCBとして十分な精度を達成していることを確認 した。今回検討したアルゴリズムは，主に $145 \mathrm{kVGCB}$ おけるコンデンサバンク・シャントリアクトルの開閉等 への適用を前提として検討を行った。今後, 残留磁束を 考慮した無負荷変圧器投入への対応など, 開閉極位相制 御装置の適用範囲を拡大していく上での課題について更 なる検討を行う予定である。

(平成 12 年 9 月 14 日受付)

\section{文献}

（1）尾崎:「高電圧電力工学」, 電気書院, 1997

(2) CIGRE Working Group 13.02: "Interruption of Small Inductive Currents. Chapter 1 and 2", ELECTRA, No.72, pp.73-103, 1980

(3) E.Andersen et al. : "Synchronous Energizing of Shunt Reactors and Shunt Capacitors", CIGRE $13-12,1988$

(4) R.J.Majotte et al. : "Field Tests of a Circuit Breaker Synchronous Control", IEEE Trans. on Power Delivery, Vol.10, No.3, 1995

(5) J.F.Reid et al. : "Controlled Switching Issues and the National Grid Company's Experience of Switching Shunt Capacitor Banks and Shunt Reactors", CIGRE 13-112, 1998

（6）山形·戸田·熊谷·石川・西脇·横田：「ガス遮断 器の開極位相制御によるシャントリアクトル電流 遮断に伴う再発弧過電圧の抑制」, 電学論B, Vol.112-B, No.2, 1992

(7) CIGRE Working Group 13.07 : "Controlled Switching of HVAC Circuit Breakers", 1398(WG 07)IWD 01, 1998

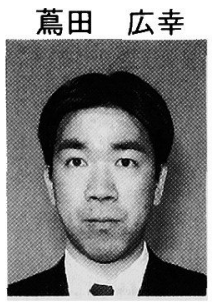

（正員）1997年 3 月大阪大学大学院基礎 工学研究科システム工学専攻修了。同 年 4 月三菱電機(株)入社。現在, 同社産 業システム研究所において，プラント 機器の信号処理技術に関する研究開発 に従事。

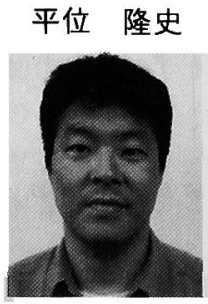

情報学会会員。
（正員）1989年3月京都大学大学院工学 研究科数理工学専攻博士後期課程研究 指導認定退学。同年 4 月三菱電機(株) 久社。現在, 同社産業システム研究所 において, 画像処理・信号処理・ネッ トワークシステムの産業㐫用に関する 研究に従事。工学博士。システム制御 
香山 治彦 （正員）1991年3月早稲田大学大学院理 工学研究科電気工学専攻修士課程修了。 同年 4 月三菱電機(株)入社。現在, 同社 系統変電・交通システム事業所, 開閉 機器製造部にて高電圧遮断器の開発設 計に従事。

伊藤 弘基 （正員）1984年3月東京工業大学大学院

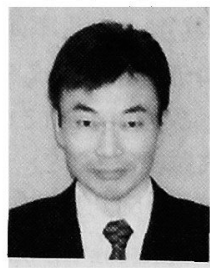
理工学研究科機械物理工学専攻修士課 程修了。同年 4 月三菱電機(株)入社後, 1989～1991年イリノイ大学に留学。現 在, 三菱電機(株)系統変電・交通シス テム事業所, 開閉機器製造部にて高電 圧遮断器の開発設計に従事。工学博士。 IEEE及びCIGRE13.07「Controlled Switching」会員。

宇佐美 照夫（正員）1971年大阪市立大学工学部応用 物理卒。1973年3月修士課程修了。同 年 4 月三菱電機(株)入社。現在, 同社産 業システム研究所にてプラント機器の 診断に関する研究に従事。計測自動制 御学会, IEEE会員。 